\section{A Temperature Overshoot on a Catalyst Pellet}

\section{K. R. Westerterp, W. C. Kusters and R. J. Wijngaarden*}

Dedicated to Professor Dr. Dr.h.c. Ewald Wicke on occasion of his 70 . birthday

\section{Introduction}

In the product separation units of ethylene cracking plants the ethylene stream contains acetylene. This acetylene has to be removed, because it hampers the ethylene polymerization. Usually this is done in a catalytic adiabatic fixed bed reactor, where the acetylene is selectively hydrogenated with an excess of hydrogen. Ideally it is converted into ethylene only, but small amounts of ethylene are also cohydrogenated. The two reactions are:

$\mathrm{C}_{2} \mathrm{H}_{2}+\mathrm{H}_{2} \rightarrow \mathrm{C}_{2} \mathrm{H}_{4}+172 \mathrm{MJ} / \mathrm{kmol}$

$\mathrm{C}_{2} \mathrm{H}_{4}+\mathrm{H}_{2} \rightarrow \mathrm{C}_{2} \mathrm{H}_{6}+137 \mathrm{MJ} / \mathrm{kmol}$

The hydrogenation reactors are known to exhibit thermal runaway rather frequently; suddenly the ethylene cohydrogenation starts full scale, thereby completely consuming the excess of hydrogene and increasing the temperature difference over the bed manifold.

A project was started in our laboratories to investigate the causes of the runaway and the dynamic behaviour of the reactor. During experiments on the reaction kinetics some unexpected phenomena were observed : it took long periods of time to reach stable conditions in a test reactor. This observation led us to a study of the behaviour of a single catalyst pellet. In this study a temperature overshoot was observed with a time constant in the order of magnitude of minutes it is this phenomenon that shall be reported here in more detail.

\section{Literature survey}

Plant conditions for the acetylene removal by hydrogenation is described a. o. in [1 - 5]; Lam and Lloyd [5] provide many operating details. The $\mathrm{C}_{2} \mathrm{H}_{2}$ content of the ethylene stream is usually reduced from 2000 to $20000 \mathrm{ppm}$ to around 1 to $5 \mathrm{ppm}$ with a Pd catalyst on a alumina carrier. The reactor inlet temperature is 50 to $80^{\circ} \mathrm{C}$ and the exit temperature depends on the amount of hydrogen converted, the adiabatic temperature rise being 30 to $40^{\circ} \mathrm{C}$ per mole percent of $\mathrm{H}_{2}$ converted. The reactor pressure varies from 1.0 to $3.5 \mathrm{MPa}$. Carbon monoxide is often added to the feed stream to moderate the catalytic activity and increase the selectivity.

The literature is not conclusive as to the reaction rate equations, but all agree upon a Langmuir-Hinshelwood or an Eley-Rideal type. Most experiments were done at atmospheric pressure. On a Pd catalyst the selectivity towards the acetylene hydrogenation is high, which is explained by the strong adsorption of $\mathrm{C}_{2} \mathrm{H}_{2}$. Probably $\mathrm{C}_{2} \mathrm{H}_{2}$ and $\mathrm{C}_{2} \mathrm{H}_{4}$ are adsorbed on different sites and the $\mathrm{C}_{2} \mathrm{H}_{2}$ is replaced by $\mathrm{H}_{2}$, as it is consumed. The selectivity deteriorates, when the $\mathrm{C}_{2} \mathrm{H}_{2}$ is replaced by $\mathrm{H}_{2}$. $\mathrm{CO}$ adsorbs on the same sites as $\mathrm{H}_{2}$, an addition of $\mathrm{CO}$ leads to a reduction of the catalyst activity, but restores its selectivity. Beeck [6] reported on a reversible deactivation of the catalyst without mentioning an influence on the catalyst pellet temperature.

Catalyst pellets can exhibit multiplicity and instabilities, e.g. oscillations. These phenomena are amply discussed in literature [6-10]. Concentration overshoot phenomena on catalyst pellets after a step

* Prof. Dr.-Jr. K. R. Westerterp, W. C. Kusters, and R.J. Wijngaarden, Chemical Reaction Engineering Laboratories, Department of Chemical Engineering, Twente University of Technology, P.O. Box 217, $7500 \mathrm{AE}$ Enschede, Netherlands. disturbance in the bulk temperature or concentration have been summarized by Bennett [10]. For temperature overshoot phenomena after a step disturbance we could not find any reference in the literature; we used the search words "dynamics", "catalyst pellet", "thermal...", "temperature ..." and "overshoot". In studies on the hydrogenation of ethylene and multiplicity $[11,12]$ temperature overshoots were not mentioned; $\mathrm{Ni}$ on alumina-silica [12] and $\mathrm{CuO} / \mathrm{Cr}_{2} \mathrm{O}_{3} / \mathrm{MnO}_{2}[11]$ were used as catalysts. Dettmer and Renken [13] indicated slow chemisorption as the cause of a concentration overshoot in an isothermal experimental reactor.

\section{Experimental set-up}

Experiments on a single catalyst pellet were executed at atmospheric pressure in a glass tube as shown in Fig. 1. In order to avoid heat losses due to conduction along the thermocouple wire, three additional catalyst pellets were mounted on the wire free from and above the main pellet of which the temperature was measured. The three other pellets will exhibit the same temperature behaviour as the main particle, so that the temperature difference along the wire is zero and heat losses due to the wire can be neglected. The temperature of the gas before and after the pellets is measured too. The gas flows upward through the tube and can be preheated, flow rate and temperature can be changed, while flow rates are measured with rotameters. Concentrations in the gas can be varied by feeding varying quantities of $\mathrm{C}_{2} \mathrm{H}_{4}, \mathrm{H}_{2}$ (and $\mathrm{N}_{2}$ ). Two types of catalysts were used: cylinders and spheres. In the cylindrical pellet we installed two thermocouples, one with the joint in the centre and one on the outer surface, according to the experimental technique of Wicke [14]. As no temperature difference could be detected between the centre and the surface, the spherical pellets were equipped only with one thermocouple with the joint in the centre of the pellet. The pellet heat conductivity is apparently large. The cylinder is an industrial pellet, see data in Table 1 ; it is a shell catalyst of the egg shell type, the maximum penetration of the Pd was less than $0.1 \mathrm{~mm}$. The spherical particles were prepared by ourselves, contained $0.025 \mathrm{wt}-\%$ of $\mathrm{Pd}$ on alumina and had a diameter of $6.7 \mathrm{~mm}$.

\section{Experimental results}

Most experiments were done with spherical particles, because of the availability of correlations for the Nusselt and Sherwood numbers.

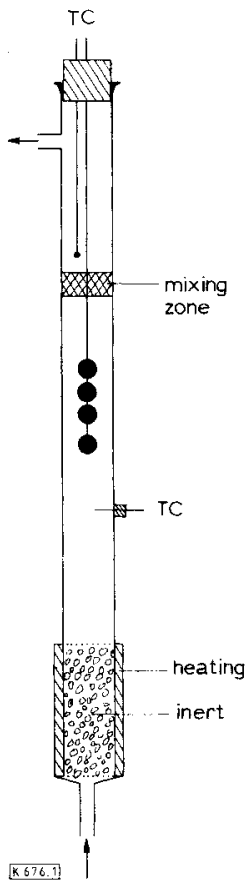

Fig. 1. The experimental set-up. Data: $d_{\mathrm{p}}=6.7 \cdot 10^{-3} \mathrm{~m}$, tube inner diameter $=15 \cdot 10^{-3} \mathrm{~m}$. 
Table 1.

Catalyst properties.

Cylinders, diameter $4.39 \mathrm{~mm}$, height $4.38 \mathrm{~mm}$

Catalyst density $1300 \mathrm{~kg} / \mathrm{m}^{3}$, bulk density $780 \mathrm{~kg} / \mathrm{m}^{3}$

Active metal surface: $350 \mathrm{~m}^{2} / \mathrm{kg}$

Internal surface: $180000 \mathrm{~m}^{2} / \mathrm{kg}$

Pd content: 0.08 wt $-\%$

Pore volume: $0.153 \cdot 10^{-3} \mathrm{~m}^{3} / \mathrm{kg}$

Experiments were started by passing $\mathrm{N}_{2}$ through the tube during appr. half an hour. Then we switched to a stream containing $\mathrm{C}_{2} \mathrm{H}_{4}$ and $\mathrm{H}_{2}$ (and in many experiments $\mathrm{N}_{2}$ as a diluent) and the temperature of the pellet was observed as a function of time. In Fig. 2 an example of the result is given: the pellet is rapidly heated up, reaches

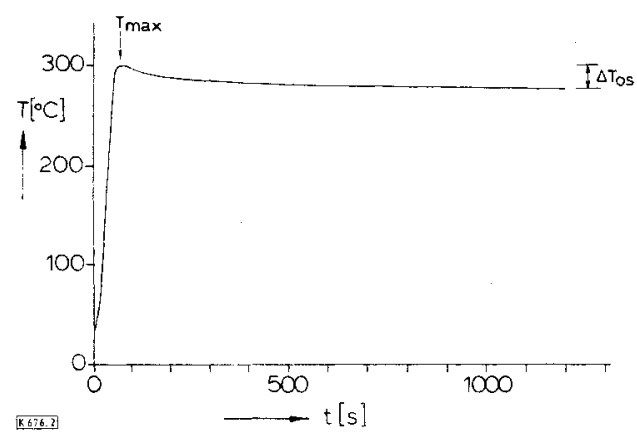

Fig. 2. An experimental curve. Data: spherical particle, gas composition $50 \% \mathrm{C}_{2} \mathrm{H}_{4}$ and $50 \% \mathrm{H}_{2}$, gas flow rate $0.62 \mathrm{~m} / \mathrm{s}$.

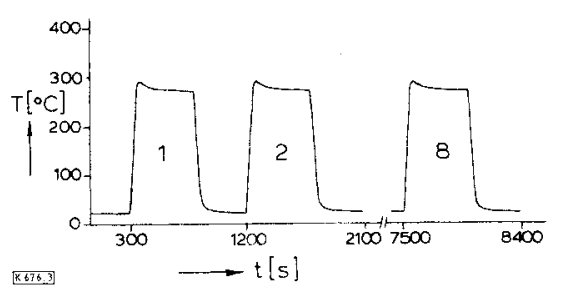

Fig. 3. A reproducibility test. Data: spherical particle, gas composition $30 \% \mathrm{C}_{2} \mathrm{H}_{4}, 20 \% \mathrm{H}_{2}$ and $50 \% \mathrm{~N}_{2}$, gas flow rate $0.21 \mathrm{~m} / \mathrm{s}$.

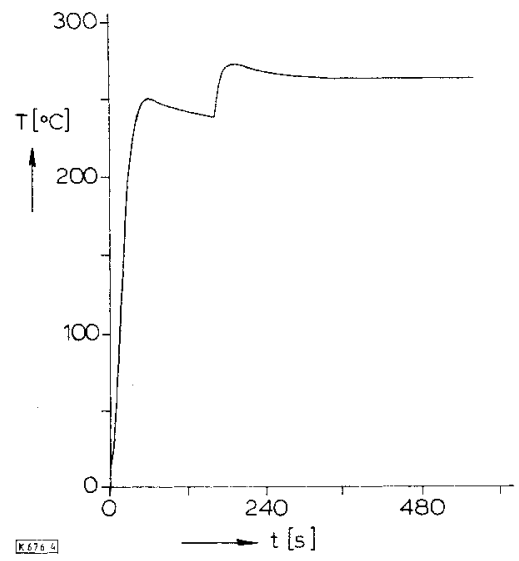

Fig. 4. An overshoot after a concentration change from $17 \%$ $\mathrm{C}_{2} \mathrm{H}_{4}, 11 \% \mathrm{H}_{2}$ and $72 \% \mathrm{~N}_{2}$ to $17 \% \mathrm{C}_{2} \mathrm{H}_{4}$ and $83 \% \mathrm{H}_{2}$ at $150 \mathrm{~s}$. Data: spherical particle, gas flow rate $1.27 \mathrm{~m} / \mathrm{s}$.

a maximum temperature $T_{\max }$ and then the temperature drops slowly till after about half an hour a steady state temperature is reached. The temperature overshoot $\Delta T_{\mathrm{OS}}$ is completely reproducible as is shown in Fig. 3, where the same experiment was repeated eight times. The overshoot phenomenon is not only found after "start-up" of the catalyst particle, but also at changing of conditions as shown in Fig. 4, where the $\mathrm{N}_{2}$ diluent was replaced by $\mathrm{H}_{2}$. Overall conversions after the four pellets are so low, that the bulk of the gas is hardly heated up. Depending on the gas flow rate the conversions varied from 0.001 to 0.04 with an average of 0.004 , which under adiabatic conditions would correspond to a temperature increase of the bulk of the gas after the first particle of 3 to $4^{\circ} \mathrm{C}$.

In Fig. $5 \Delta T_{\text {Os }}$ as observed is plotted as a function of the Sherwood number and in Fig. 6 as a function of the bulk temperature of the gas.

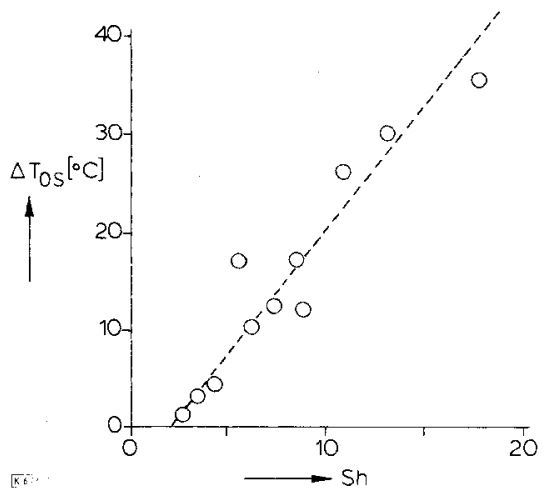

Fig. 5. The temperature overshoot as a function of the calculated Sherwood number.

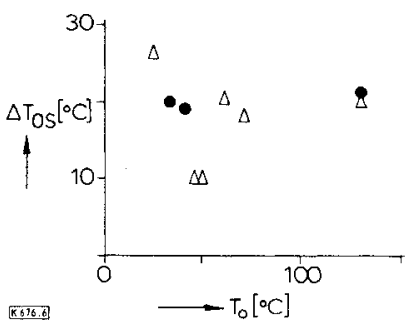

Fig. 6. The temperature overshoot as a function of the temperature of the bulk of the gas. Flow rates are $0.21 \mathrm{~m} / \mathrm{s}(\Delta)$ and $0.62 \mathrm{~m} / \mathrm{s}$ $(\bullet)$, spherical particles.

The Sh number is calculated with the relation: $\mathrm{Sh}=2.0+0.6 \times$ $\mathrm{Re}^{0.5} \mathrm{Sc}^{0.33}$. The Reynolds number is taken at the velocity of the gas around the pellet and based on the empty cross-section. Physical properties are taken at the average film temperature.

The experimental results indicate, that the maximum pellet temperatures strongly depend on the gas composition and that the temperature overshoots do depend on the gas flow rate and gas composition, but hardly do so on the temperature of the bulk of the gas. A cross plot indicates that $\Delta T_{\mathrm{OS}}$ is approximately $\simeq \sqrt{\mathrm{Re}}$.

\section{Interpretation of the results}

As discussed in [15] for complete mass transfer resistance the pellet temperature would $b^{1)}$ :

$T_{\mathrm{i}}-\bar{T}=\frac{k_{\mathrm{G}}}{\alpha} \bar{c}\left(-\Delta H_{\mathrm{r}}\right)=\Delta T_{\mathrm{ad}} \mathrm{Le}^{-0.67}$.

The influence of the Lewis number Le was proven by Wicke [16]. If applied to our system and to a 1:1 mixture of $\mathrm{C}_{2} \mathrm{H}_{4}$ and $\mathrm{H}_{2}$ we would find $\Delta T_{\mathrm{ad}} \simeq 3300 \mathrm{~K}$ for the adiabatic temperature rise. This means that our experiments are not completely mass transfer controlled. They also can not be pore diffusion controlled, because we have a shell catalyst with an extremely thin layer of Pd on the outer pellet surface. They also can not be pellet heat conduction controlled, because we could not detect any temperature difference between the

1) A list of the symbols is at the end of the paper. 
centre and the outer surface of the pellet: with our instrumentation we slould have detected a temperature difference of $0.5^{\circ} \mathrm{C}$. There is also no permanent deactivation of the catalyst because of the full reproducibility of the experiments. So we may conclude that the overshoot phenomenon is partly mass and/or heat transfer controlled (because of the influence of Re) and partly kinetically controlled. In the initial stage the chemical rate is high, but it is gradually slowed down due to some reversible kinetic mechanisms.

As a possible explanation - which we cannot prove - we assume a slow adsorption on the catalyst of one of the components taking part in the reaction. Further we assume an Eley-Rideal mechanism. in which the chemisorbed hydrogen reacts with ethylene in the gas phase. Due to the slow adsorption of ethylene the number of active sites available for hydrogen is gradually reduced : the reaction rate is slowed down. For an Eley-Rideal mechanism with chemisorbed hydrogen reacting with gaseous ethylene and with the active sites partly blocked by adsorbed ethylene, we would have the following rate expression:

$R^{n}=\frac{k^{n} K_{\mathrm{H}} \mathrm{c}_{\mathrm{Hi}} c_{\mathrm{Ei}}}{1+K_{\mathrm{H}} c_{\mathrm{Hi}}+K_{\mathrm{EC}} \mathrm{Es}_{\mathrm{s}}}$.

Now assuming that $K_{\mathrm{H}} c_{\mathrm{Hi}}+K_{\mathrm{E}} \mathcal{C}_{\mathrm{Es}} \gg 1$ and dividing by $K_{\mathrm{H}} c_{\mathrm{Hi}}$ we obtain the simplified rate expression:

$R^{\prime \prime}=\frac{k^{\prime \prime} c_{E \mathrm{i}}}{1+K_{C_{\mathrm{ES}}}}\left(\frac{\mathrm{kmol} \text { converted }}{\mathrm{m}^{2} \text { outer surface }}\right)$

in which $K=K_{\mathrm{E}} / K_{\mathrm{H}} c_{\mathrm{Hi}}, c_{\mathrm{Ei}}$ the concentration of ethylene in the gas phase at the outer surface of the catalyst pellet $\left(\mathrm{kmol} / \mathrm{m}^{3}\right)$ and $c_{\mathrm{Es}}$ of the adsorbed ethylene $(\mathrm{kmol} / \mathrm{kg}$ catalyst). As the mass transfer coefficient for hydrogen is around four times higher than that for ethylene, we assumed $c_{\mathrm{Hi}}$ constant during an experiment. For the mass transport to the catalyst surface holds:

$k_{\mathrm{GE}}\left(\bar{c}_{\mathrm{E}}-c_{\mathrm{Ei}}\right)=R^{\prime}$

if the accumulation of mass in the surrounding film is neglected. For the slow adsorption of ethylene, blocking the active sites, a mass balance gives:

$\frac{\mathrm{d} c}{\mathrm{Es}} \cdot=k\left(m c_{\mathrm{Ei}}-c_{\mathrm{Es}}\right)$

Here $m$ is a distribution coefficient, which has been determined with the Thermogravimetric Analyser, $k$ is a transfer coefficient. The heat balance of the particle leads to the following expression:

$\left(\varrho c_{\mathrm{p}}\right)_{\mathrm{c}} \frac{d_{\mathrm{p}}}{6} \frac{\mathrm{d} T_{\mathrm{i}}}{\mathrm{d} t}=\left(-\Delta H_{\mathrm{r}}\right) R^{n}-\alpha\left(T_{\mathrm{i}}-\bar{T}\right)-\sigma\left(T_{\mathrm{i}}^{4}-\bar{T}^{4}\right)$

in which $\bar{T}$ is the temperature of the bulk of the gas and $T_{\mathrm{i}}$ of the catalyst particle. The heat losses due to radiation could not be neglected. With the equations above an experimental curve was approximated. As fitting parameters $k$ and $K$ were used. The results for one experiment is given in Fig. 7, together with the mathematical approximation. For the activation energies data from literature were taken [6]. The approximation reasonably covers the measured data. We did not apply a regression analysis, because of the speculative nature of the model interpretation of the overshoots. Also a Langmuir-Hinshelwood mechanism can be used to explain the temperature overshoot, essential is only the slow adsorption.

\section{Discussion}

From Fig. 5 we can see that the temperature overshoot is approximately linearly dependent on the Sherwood number Sh for the pellet. A fit would give $\Delta T_{\mathrm{OS}}=2.6(\mathrm{Sh}-2.0)$. At no flow of gas around the particle $(\mathrm{Sh}=2.0)$ there would be no temperature overshoot. However, we cannot distinguish whether it is the Nusselt number or Sh, which is the relevant parameter, because of the Chilton-Colburn analogy. If $\mathrm{Sh}$ is higher, the concentration of the reactants at the

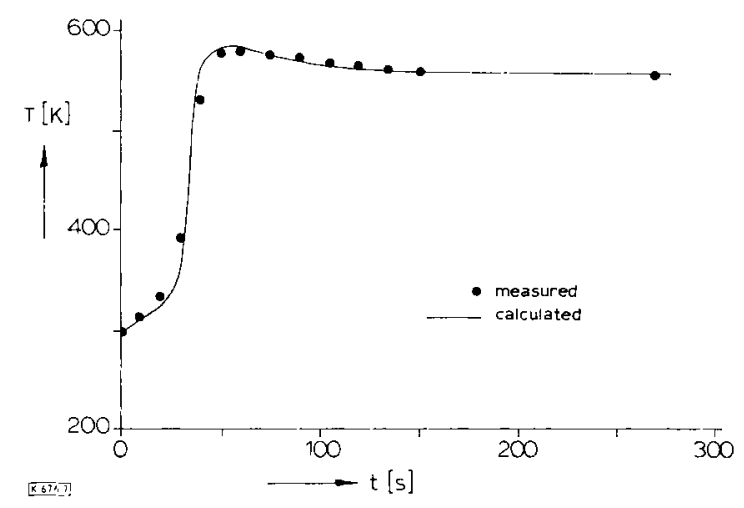

Fig. 7. Measured points and calculated curve. Data used: $\alpha=142$ $\mathrm{W} / \mathrm{m}^{2} \mathrm{~K}, \quad k_{\mathrm{G}}=0.107 \mathrm{~m} / \mathrm{s}, c_{\mathrm{E}}=20.2 \cdot 10^{-3} \mathrm{kmol} / \mathrm{m}^{3}, k^{n}=3500$ $\exp \left(-4600 / T_{\mathrm{j}}\right) \mathrm{m} / \mathrm{s}, K=65 \cdot 10^{9} \exp \left(-5500 / T_{\mathrm{i}}\right) \mathrm{kg} / \mathrm{kmol}$ and $k=0.025 \mathrm{~s}^{-1}$; further $\mathrm{Re}=190$ and 50 vol. $-\% \mathrm{C}_{2} \mathrm{H}_{4} / 50$ vol. $-\% \mathrm{H}_{2}$.

interface is higher and so are the reaction rates, so the particle is heated up quicker. The simultaneous but slow adsorption in the mean time has not yet reached a stage, where the reaction is seriously slowed down. Simultaneously, if $\mathrm{Nu}$ is higher the heat loss rate from the particle is higher and the pseudo-equilibrium between heat production and heat loss is reached quicker, whereas in the meantime the slow adsorption continues. Consequently temperature overshoots are larger at higher Sh-numbers or Nu-numbers. We feel that the ratio $k_{\mathrm{G}} / k d_{\mathrm{p}}$ or $\alpha / \varrho c_{\mathrm{p}} k d_{\mathrm{p}}$ is determining the magnitude of the temperature overshoot.

We realise that this interpretation to explain the temperature overshoot is speculative. In our reaction engineering laboratories we have no equipment to investigate what really happens on the surface of the catalyst. We therefore would highly appreciate if catalytic engineering colleagues would further pursue the investigation of the real causes of these overshoots. We hope that at least it has become clear that we must dedicate more efforts to the study of catalyst dynamics. The overshoot after a concentration change - for the industrial, cylindrical catalyst we have measured values of $\Delta T_{\mathrm{OS}}$ of even $60 \mathrm{C}$ - are of real importance, because they are high enough to initiate the ethylene hydrogenation in an acetylene removal reactor and to cause in that way the runaways that occur in industrial practice.

Received: March 30, 1984 [K 676]

\section{Symbols}

\begin{tabular}{|c|c|c|}
\hline$c_{\mathrm{p}}$ & {$[\mathrm{J} / \mathrm{kg} \mathrm{K}]$} & specific heat \\
\hline$c^{\prime}$ & {$\left[\mathrm{kmol} / \mathrm{m}^{3}\right]$} & concentration \\
\hline $\bar{c}$ & {$\left[\mathrm{kmol} / \mathrm{ml}^{3}\right]$} & concentration in the bulk of the gas \\
\hline$d_{\mathrm{p}}$ & [m] & pellet diameter \\
\hline$-\Delta H_{\mathrm{r}}$ & {$[\mathrm{J} / \mathrm{kmol}]$} & reaction heat \\
\hline$k$ & {$\left[\mathbf{s}^{-1}\right]$} & adsorption rate coefficient \\
\hline$k^{\prime \prime}$ & {$[\mathrm{m} / \mathrm{s}]$} & kinetic rate constant \\
\hline$k_{\mathrm{G}}$ & {$[\mathrm{m} / \mathrm{s}]$} & mass transfer coefficient \\
\hline$K$ & [kg cat. $\mathrm{kmol}]$ & adsorption constant \\
\hline$m$ & [ $\mathrm{m}^{3}$ gas $/ \mathrm{kg}$ cat. $]$ & distribution coefficient \\
\hline$R^{\prime \prime}$ & {$\left[\mathrm{kmol} / \mathrm{m}^{2} \mathrm{~s}\right]$} & reaction rate per unit of surface area \\
\hline$T$ & [K] & temperature \\
\hline $\bar{T}, T_{\mathrm{o}}$ & {$[\mathrm{K}]$} & temperature of the bulk of the gas \\
\hline$\Delta T_{\text {iat }}$ & [K] & adiabatic temperature rise \\
\hline$\alpha$ & {$\left[\mathrm{W} / \mathrm{m}^{2} \mathrm{~K}\right]$} & heat transfer coefficient \\
\hline$\sigma$ & {$\left[\mathrm{W} / \mathrm{m}^{2} \mathrm{~K}^{4}\right]$} & Stefan-Boltzmann constant \\
\hline \multicolumn{3}{|c|}{ Subscripts } \\
\hline c & \multicolumn{2}{|c|}{ catalyst } \\
\hline E & \multicolumn{2}{|c|}{ ethylene } \\
\hline $\mathrm{H}$ & \multicolumn{2}{|l|}{ hydrogen } \\
\hline & \multicolumn{2}{|c|}{ at or of the pellet } \\
\hline
\end{tabular}


$\max$ highest temperature reached

OS overshoot

s adsorbed

\section{References}

[1] Lobo Aza, E.: Afinidad 35 (1978) p. 463.

[2] Reitmeier, R. E.; Fleming, H. W.: Chem. Eng. Prog. 54 (1958) Nr. 2, p. 48

[3] Andersen, H. C.; Haley, A. J.; Egbert, W.: Ind. Eng. Chem. 52 (1952) p. 901.

[4] Huang, W.: Hydrocarbon Process. 58 (1979) Nr. 10, p. 131.

[5] Lam, W. K.; Lloyd, L.: Oil Gas J. 70 March 27 (1972) p. 66.
[6] Beeck, O.: Discuss. Faraday Soc. (1950) p. 118.

[7] Luss, D.: Symposium of Chemical Reaction Engineering, Heidelberg, p. 487, Dechema, Frankfurt/M. 1977.

[8] Schmitz, R. A.: Adv. Chem. Ser. 148 (1975) p. 156.

[9] Sheintuch, M.; Schmitz, R. A.: Catal.Rev.-Sci. Eng. 15 (1977) p. 107.

[10] Bennett, C. O.: Catal. Rev.-Sci. Eng. 13 (1976) p. 121.

[11] Furasawa, T.; Kunii, D.: J. Chem. Eng. Jpn. 4 (1971) p. 274.

[12] Hughes, R.; Koh, H. P.: Chem. Eng. J. 1 (1970) p. 185.

[13] Dettmer, D.; Renken, R.: Chem.-Ing.-Tech. 55 (1983) p. 146.

[14] Wicke, E.: Adv. Chem. Ser. 109 (1972) p. 183.

[15] Westerterp, K. R.; van Swaaij, W. P. M.; Beenackers, A. A.C. $M$.: Chemical Reactor Design and Operation, 2nd ed., Wiley, New York 1984.

[16] Wicke, E.: Z. Elektrochem. 65 (1961) p. 267.

\section{Abgasreinigung mit fixierten Bakterien- Monokulturen}

\section{Kurt Kirchner, Gerhard Hauk und Hans-Jürgen Rehm*}

\section{Herrn Professor Dr. Dr. h.c. Ewald Wicke zum 70. Geburtstag}

Die biologische Abgasreinigung kommt bislang nur in speziellen technischen Bereichen, bei denen beispielsweise mit Geruchsemissionen zu rechnen ist, zum Einsatz. Die bisher eingesetzten biologischen Abgasreinigungsverfahren lassen sich grob in trockene und nasse Verfahren unterteilen. Bei den trockenen Verfahren werden die Abgasströme durch biologisch aktive Filterschichten aus Erde, Kompost, Torf u. ä. geführt, wobei die zu beseitigenden Abgaskomponenten sorbiert und schließlich biologisch umgesetzt werden [1] Bei den nassen biologischen Reinigungsverfahren werden die Schadstoffe hingegen in Waschkolonnen, in welchen Bakterien-Suspensionen (meist verdünnte Klärschlämme) als Waschflüssigkeiten verwendet werden, absorbiert. In der Kolonne und/oder in einem getrennten Reaktor setzen die suspendierten Bakterien die gelösten Schadstoffe um, wodurch die Waschflüssigkeit wieder für den Absorptionsprozeß regeneriert wird [2].

Obgleich die Wirtschaftlichkeit derartiger Verfahren längst bekannt ist [3], werden sie von der Praxis zurückhaltend aufgenommen, und zwar auch dann, wenn die zu beseitigenden Abgasbestandteile biologisch abbaubar sind. Dies wird oft mit langen Anpassungszeiten (Adaptation) der Biomasse (insbesondere bei größeren Diskontinuitäten im Abgasstrom) oder geringen raumspezifischen Reinigungsleistungen (Raumgeschwindigkeiten) begründet. Die vorliegende Arbeit befaßt sich mit den reaktions- und verfahrenstechnischen Grundlagen eines Biofestbettreaktors ${ }^{11}$ mit dem Ziel, geschwindigkeitsbestimmende Einflußgrößen aufzuzeigen.

\section{Material und Versuchsmethoden}

Als Filtermaterial wurde Aktivkohle, ein seit vielen Jahren in der biologischen Abwasserreinigungstechnik erfolgreich eingesetztes Adsorptions- und Trägermaterial für Schadstoffe und Mikroorganismen, verwendet $[4-6]$. Bei den Versuchen kam ein granulierter abriebfester Aktivkohle-Typ (Merck, Art. Nr. 1/02515-2) mit einer

* Prof. Dr. K. Kirchner, Dipl.-Ing. G. Hauk, Dechema-Institut, Theodor-Heuss-Allee 25, 6000 Frankfurt/M. 97, und Prof. Dr. H.-J. Rehm, Institut für Mikrobiologie, Westfälische WilhelmsUniversität, Tibusstr. 7-15, 4400 Münster/Westf.

1) Zum Patent angemeldet am 19. 12. 1983.
Partikelgröße von $2,5 \mathrm{~mm}$ und einer inneren Oberfläche von $1250 \mathrm{~m}^{2} / \mathrm{g}$ unter einer ähnlichen Zielsetzung wie bei der Abwasserreinigung zum Einsatz, z. B.: Erhöhung der räumlichen Zelldichte und Erhöhung der mikrobiellen Aktivität.

Die Anforderungen an Abgasreinigungsverfahren wurde dahingehend berücksichtigt, daß das als Träger dienende Aktivkohle-Granulat nicht wie bei den meisten Abwasserreinigungsverfahren in suspendierter Form, sondern in einer Schüttung mit einem Gesamtvolumen $V_{\mathrm{k}}$ von $50 \mathrm{~cm}^{3}$, in welcher niedrige Druckverluste auftreten, vorlag. Als Bakterien kamen die Stämme Pseudomonas fluorescens (DSM 50090) sowie Rhodococcus sp. (DSM 43001) und als Modellschadstoffe verschiedene Lösungsmittel, die dem Abgas bis zu 40 ppm zugesetzt wurden, zum Einsatz.

In Abb. 1 ist die Versuchsanordnung dargestellt. Der Biofestbettreaktor 1 hat einen Durchmesser von $45 \mathrm{~mm}$. Die Zellimmobilisierung fand nach einer in [5] näher beschriebenen Methode statt. Eine 2- bis 3stündige Berieselung der Aktivkohle-Schüttung 1 im Kreislaufsystem mit Bakterien-Suspensionen, deren Zellkonzentration 0,8 bis $1,1 \mathrm{~g}$ Trockensubstanz/1 betrug, führte zu einer adsorptiven Belegung an der Aktivkohle-Oberfläche. Anschließend tauschte man die Suspension gegen eine Minerallösung (Einzelheiten vgl. [7]) aus. Das Abgas strömte von unten im Gegenstrom zu der herabrieselnden Minerallösung durch die zellbeladene Aktivkohle-Schüttung. Die Schadst offdosierung erfolgte durch eine Kapillardosierzelle 6 . Aus dem Gefäß 3 konnte die dem System entwichene Minerallösung zudosiert werden, so daß der Flüssigkeitsstand im Auffanggefäß 2 konstant blieb. Die Betriebstemperatur $T$ lag bei $24^{\circ} \mathrm{C}$. Mit einer $0,1 \mathrm{n} \mathrm{HCl}$ - (4) bzw. $0,1 \mathrm{n} \mathrm{NaOH}$-Vorlage 5 wurde ein pH-Wert von 7 eingestellt. Die Schadstoffkonzentration in der Gasphase wurde fortlaufend vor und nach der Schüttung 1 aufgezeichnet. Eine genaue zeitabhängige Quantifizierung der Zellmasse in der Schüttung bedarf weiterer Untersuchungen.

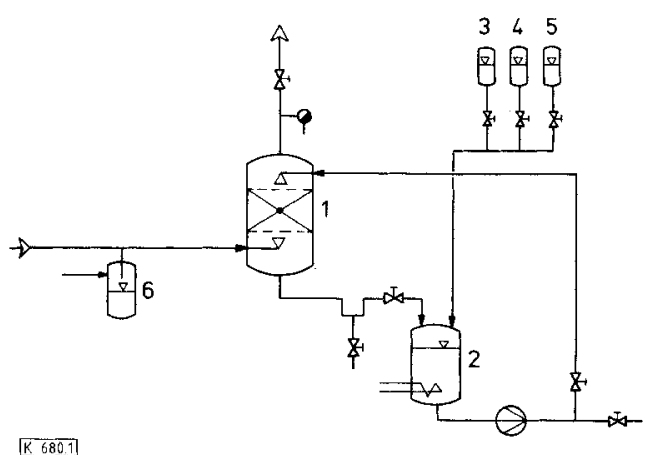

Abb. 1. Versuchsanlage Biofilter; Näheres s. Text. 